\title{
Moving Memories of Slavery among West African Migrants in Urban Contexts (Bamako, Paris)
}

Mémoires itinérantes de l'esclavage chez les migrants ouest-africains en contexte urbain (Bamako, Paris)

Memorias de esclavitud en movimiento entre migrantes de África occidental en contextos urbanos (Bamako, Paris)

Lotte Pelckmans

\section{OpenEdition}

\section{Journals}

\section{Electronic version}

URL: https://journals.openedition.org/remi/6266

DOI: $10.4000 /$ remi.6266

ISSN: $1777-5418$

Publisher

Université de Poitiers

\section{Printed version}

Date of publication: 1 March 2013

Number of pages: $45-67$

ISBN: 979-10-90426-07-8

ISSN: 0765-0752

\section{Electronic reference}

Lotte Pelckmans, "Moving Memories of Slavery among West African Migrants in Urban Contexts (Bamako, Paris)", Revue européenne des migrations internationales [Online], vol. 29 - n¹ | 2013, Online since 01 March 2016, connection on 14 April 2022. URL: http://journals.openedition.org/remi/6266 DOI: https://doi.org/10.4000/remi.6266 


\section{Moving Memories of Slavery among West African Migrants in Urban Contexts (Bamako, Paris)}

\section{Lotte Pelckmans ${ }^{1}$}

Migrants' movements reflect embodied memories of the slave past. Internal African slavery has long existed in the West African Sahel as an economic (Meillassoux, 1975: 15-16), legal (Botte, 1999a) and social (Meillassoux, 1986) system. Although most aspects of slavery had been legally and economically abolished since the beginning of twentieth century, people in former slave societies socially continue to practice an "ideology of slavery" (Lovejoy, 1981: 1-8) whereby ancestry defines one's social status. This ideology of slavery is present among specific ethnic groups (such as Soninke, Fulbe, Tuareg and Moors) in several West African countries (Rossi, 2009a). ${ }^{2}$

The memory of internal African slavery reproduces unequal social relations and statuses today, but people know very well how "to keep quiet about it" (Zempleni, 1996). In public debates, most West African nations have remained silent on the topic of internal slavery (Hahonou and Pelckmans, 2012). This absence of public commemorations of African slavery has been explained as a result of colonial silences and interests, nation building, funding possibilities and self-imposed silences (Thioub, 2005; De Jong, 2010; Rodet, 2010b). This is why in the European sense of the term, public and official discursive "memory work" about internal African slavery is almost non-existent in Africa. Instead, Argenti and Röschenthaler, (2006: 33) have argued that the African slave past is at present "insistently recurring in manifold non-discursive, performative genres". So the memory work of internal slavery in West Africa is not done through speech or discourse, but through the body and embodiment. This echoes Rosalind Shaw's (2002) argument that dance, cults and songs are important sites of non-discursive memories of slavery in contemporary Sierra Leone. This article extends the idea of "non-discursive memory work" to include migration and movements of

\footnotetext{
1 Postdoctoral researcher, Institute for History, Leiden University, the Netherlands; L.pelckmans@hum.leidenuniv.nl. Research for this article was possible thanks to a Dutch WOTRO/NWO grant (2005-2009) and the writing was done during a Fernand Braudel Scholarship in Paris (2012). I sincerely thank Paolo Gaibazzi, Marie Rodet, Eric Hahonou and John Parker for their comments on the first draft of this article.

2 Some key examples are Mali (Diawara, 1989/1990; Pelckmans, 2011; Keita, 2012), Mauritania (Ruf, 1999; Ould Ahmed Salem, 2003; Leservoisier, 2005 and 2009), Niger (Vereecke, 1994; Rossi, 2009a; Hahonou, 2010), BurkinaFaso (Riesman, 1992; Bouman, 2002).
} 
people. Movements are thus analysed as non-discursive, embodied memory work of internal slavery in West Africa.

Migrants with slave status respond to the (declining) ideology of slavery through their movements. Sociologist Hirshman (1970) proposed three main forms of behaviour towards declining organisations: either people try to "exit" and disappear, either they try to find benefit from an attitude of "loyalty", or they explicitly "voice" their discontent. This model of voice, exit and loyalty could also be applied to the declining ideology of slavery among West African migrants. However, when connecting this model to migration and movement, more nuance about the temporalities of different behavioural responses is needed. Elsewhere I proposed an applied typology that puts movement at the centre of analysis and refines the three behaviours described by Hirshman into five ways of relating slave status and movement: moving with, moving back into, moving out, moving up and moving against social status (Pelckmans, 2011: 221-249). This typology puts movement at the centre of analysis and decomposes Hirshman's options in temporal versus more structural forms of movements in relation to behaviour of loyalty, exit or voice. People can be loyal on a temporal basis and "move back into" slave status or they can "move with" slave status in a more structural sense. The "exit" options correspond to (temporally) "moving out" of slave status by acquiring a new ethnic identity and name (Pelckmans, 2013fc). Thirdly, people with slave status who decide to "voice" their discontent "move up" or "move against" slave status, which means engaging in active protest against the stigmatisation of their social group (Hahonou and Pelckmans, 2011). None of these options necessarily excludes others: an individual can start his migration career by "moving with" slave status in loyalty and later on exit by "moving out" of slave status. The proposed typology of different forms of movement reflects possibilities for migrants with slave status to engage with the memory of internal African slavery.

A few scholars explicitly linked mobility to emancipation from slave status. Some focussed on the past when describing the exodus and fleeing of slave groups in the era of the abolition of slavery (Miers and Willis, 1997; Manchuelle, 1997; Klein and Roberts, 1989; Lefevbre, 2013fc; Mauxion, 2012). Others analysed movements of contemporary migrant with slave status in West Africa (Boyer, 2005; Argenti and Röschenthaler, 2006; Rossi, 2009b; Bellagamba, 2009; Gaibazzi, 2010; Pelckmans, 2012). This literature on intersections of slave status and migration (see for example Boyer, 2005; Rossi, 2009b) focuses on voice and exit options. The assumption is that migration to urban contexts can make people with slave status exit the ideology of slavery thanks to engagement with new ideologies, such as access to colonial education (Hesseling and Van Dijk, 2005; Pelckmans, 2012a); international development institutions (Giuffrida, 2005) and access to the global monetary economy (Hardung, 1998: 219). This text proposes to critically engage with such optimistic expectation of the trajectories of migrants with slave status in cities.

Urban spaces multiply possibilities for social relations and for redefining one's social status and identity and have the potential for migrants to move out/ up or against their slave status. However, several factors nuance this optimistic picture. Many migrants can for example end up in hostile environments in which they face xenophobia, racism and other forms that contribute to downward social 
mobility (Rossi, 2009a; Viti, 2005). Also, gender, age and position in the home society facilitate or impede the forms of movement both within and towards cities. A handful of scholars did signal how categorical slavery did not disappear overnight in urban diaspora's (Sy, 2000; Botte, 2011; Boyer, 2005; Pelckmans, 2007, 2011 and 2012). Gaibazzi (2012: 215-217) showed how the effects of status and rank among Gambian Soninke migrants outlasted emancipation. This "rank effect" explains how a delay in access to migration is caused by categorical slavery: one's social status (rank) impacts directly on the capacity to out-migrate. This article proposes to push this rank argument further in order to analyse to what extent not only out-migration, but also various other forms of movement rank people in relation to their social status. To do so, moving with and moving back into slave status will be analysed as non-discursive "memory work" of slavery between Fulbe migrants from Central Mali in the city of Bamako, Mali. This case material will then be compared to studies about Fulbe and Soninke migrants from West Africa (Mali, Mauritania, Senegal) in Paris, France.

Data are based on long-term, multi-sited PhD fieldwork among a network of former masters and slaves and were mainly gathered between 2001 and 2007 in Mali. The network consists of members of the political elite with freeborn status and their former slaves in rural central Mali (in and around Douentza) and urban Bamako. In order to establish trust, observations and interviews were focused on one single-family network, with which I lived for extended periods of time in the rural home village, in Bamako and in Paris. Although it is difficult to quantify this network in terms of absolute numbers, in Bamako alone I interviewed members of about thirty nuclear families from central Mali with either freeborn or slave status. The total number of persons interviewed in Bamako exceeds fifty. Only two members of this specific network reside in Paris. However, in Paris I interviewed migrants from various ethnic groups and countries (Mali, Mauritania, Senegal), during prolonged stays in 2005 and 2012. Data have been continuously updated by phone (Pelckmans, 2009) and by scattered visits to both Paris and Mali over the past years.

\section{Tracking Slavery, Memory and (Im-)mobility beyond Abolition}

The intensity of slavery in several old states of the Sahel has been distinguished from other societies, where fewer slaves were kept, by the term "slave societies" (Finley, 1981: 103). The abolition of internal slavery was proclaimed in French West Africa in 1905 (Kopytoff and Miers, 1977; Klein, 1998; Klein and Miers, 1999). The French colonial regime managed in most places to reduce slavery officially to an illegal institution but could not prohibit the related sociocultural practices and ideologies (Klein, 1998). Although the slave trade had been rather successfully abolished in French West Africa, most existing groups of already enslaved did not obtain true social or economic freedom because elites maintained monopolies on land, spouses and positions of authority (Botte, 1999a). 


\section{Tracking Slavery}

Social status continues to be transferred among the generations, despite the fact that slavery has disappeared. The ancestors of those who today enjoy ascribed freeborn status used to raid slaves as warriors or had authority as religious or political elites. And those who have slave status today have not been enslaved, but their ancestors have. In between there is the "intermediary" status group with caste-like status. The terminology that refers to "slave" or "freeborn (elite)" status refers to the current social status of individuals and families assigned to them on the basis of the position of their ancestors during the slave era. Although this terminology may appear anachronistic, informants use these terms in both vernacular and French language. The actual meaning of these words differs according to place and time. Current practices of stigmatization and discrimination related to this ideology are defined as "categorical slavery" by Rossi (2009a: 5$).^{3}$

Today, the hierarchical organization of social status among Fulbe in the Sahel reflects the previous positions of different groups in these so-called "slave economies". In the Sahelian context, similar ideologies of slavery were shared by neighbouring ethnic groups, such asTuareg, Moors and Songhay (Breedveld and de Bruijn, 1996; Amselle, in de Bruijn et van Dijk, 1997: 10). Although the majority of people with slave status in the Sahel are now economically free, several former slave groups continue to be discriminated due to the stigma of having slave ancestors, which stains their genealogy (Pelckmans, 2014fc). Furthermore, freeborn groups in many localities managed to maintain the monopoly on politics, spouses, land and property. Several studies demonstrated how there is a continued stigmatization of groups of descendants of slaves in several realms. Botte (2003) and Ould Ahmed Salem (2002) described how social status is embedded in the legal framework of Islam, which recognizes that persons can be property. Others (Hall, 2005; Schmitz, 2006) indicate how in Sahelian societies, slavery may not have been racist per se (as in the Americas) but rather racialised. Those formerly enslaved are discriminated against in racial terms and, in Fulbe society, descendants of slaves continue to be referred to as "blacks" (Baleebe). Besides such disqualifying discourse with reference to race, other forms of discrimination of people with slave status persist. Several scholars working on Fulbe in West Africa (Riesman, 1977; Clark, 1999; Fay, 2002; Schmitz, 2009; Leservoisier, 2005 and 2009) have analysed contemporary differences in access to labour, education, politics, marriage. This discrimination generates complex dilemmas for people of slave status (de Bruijn and Pelckmans, 2005).

\section{Tracking Mobility}

Being mobile and on the move is a way of life associated with groups of freeborn Fulbe nomads in the West African Sahel (Dupire, 1970; de Bruijn and van Dijk, 1995; Botte et al., 1999: 25). This stereotype is based on the Fulbe's selfimage as nomads, as well as on ethnic stereotypes ascribed to Fulbe by their

\footnotetext{
3 Confusingly, in West African societies, categorical slavery co-exists with various other references to slavery: historical, metaphorical and extraverted practices of modern slavery (Rossi, 2009a: 5). Of these different ways in which slavery manifests itself, only historical slavery can be considered an actual type of slavery, while all the other references are about abuse and discrimination similar to slavery.
} 
Map 1: Haayre region and Gourma region. Overview of former Fulbe kingdoms Booni, Dalla and Joona ruled by freeborn elite families

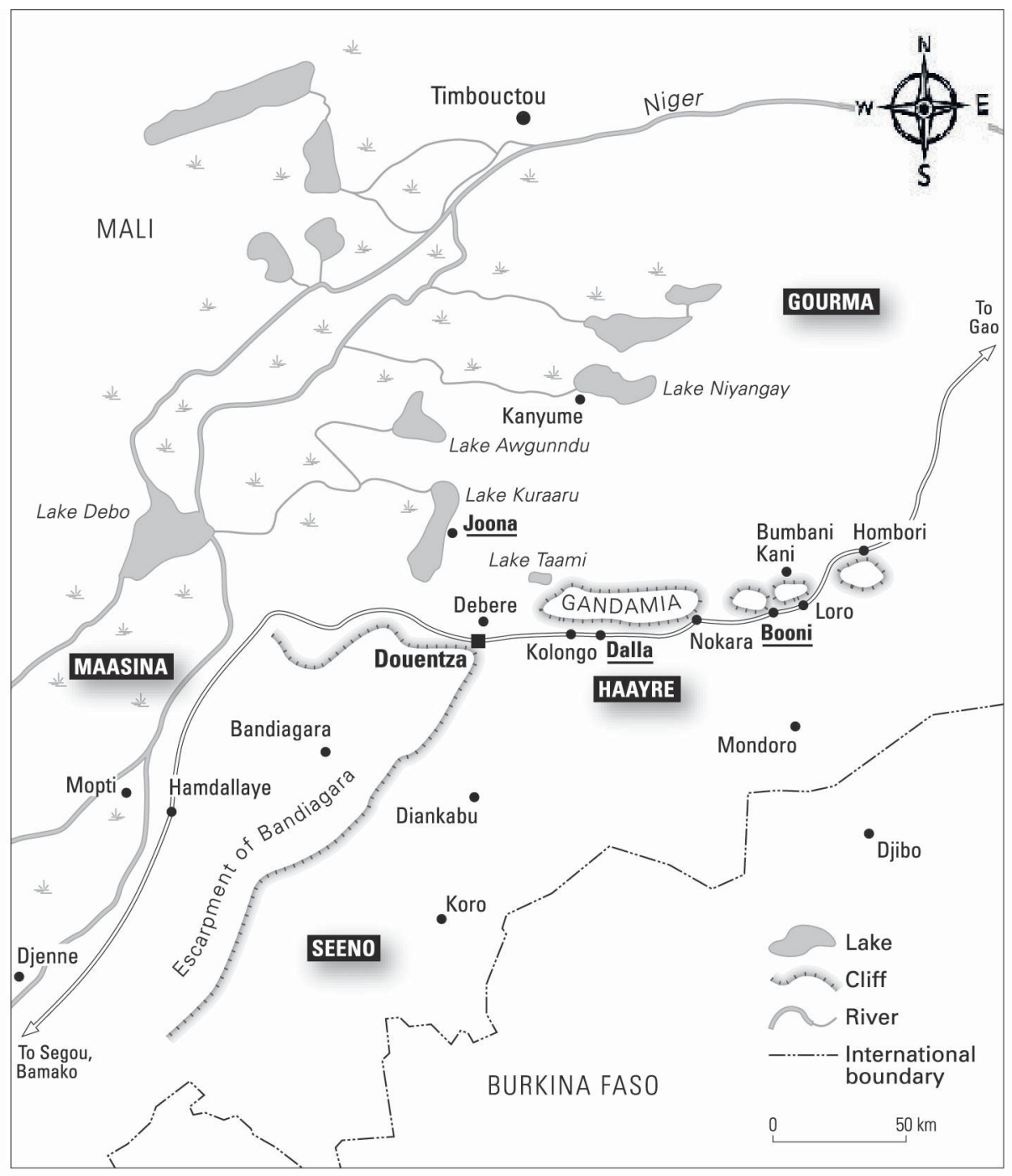

Source: Nel De Vink mapdesign. 
neighbours (Amselle, 1996; de Bruijn and van Dijk, 1997). Historically, some "freeborn" social groups of Fulbe in central Mali have in fact become extremely immobile and sedentarised. This immobility has facilitated their control over conquered territories and people, as is the case of a group of Fulbe warriors who sedentarised in the nineteenth century Islamic Diina Empire of Maasina (Sanankoua, 1990; Klein, 1998: 47). Some of these warriors, called Weeheebe in Fulfulde, settled on the outskirts of the empire in a region called the Haayre (Map 1). Today they continue to be distinguished from other freeborn elite families by their patronym Dicko. ${ }^{4}$ The network of Dicko families in Bamako is central to the analysis in this article.

One central aspect of power and nobility in the Haayre region was control over the mobility of others. From the outset, enslavement meant that a person was forced to go and live elsewhere, and this removal through capture was an explicit form of "forced migration" (Lovejoy, 2009). Slaves were either immobilized or forced to move but had no freedom of movement. ${ }^{5}$ Nevertheless, some tried to become mobile and fled their host societies when too oppressive. ${ }^{6}$ In Mali the slave exodus from Banamba that followed abolition in 1905 has been well documented (Klein and Roberts, 1980). However, in Central Mali, no single collective slave revolts by runaway slaves were reported in the colonial archives. The region of central Mali was typically a "frontier region" (Kopytoff, 1987) and escape was difficult because of insecurity and instability due to raiding warlords (Lefevbre, 2013fc).

The stereotype of Fulbe as nomadic pastoralists with mobile lifestyles has tended to obfuscate the different forms and qualities of movement of different status groups in Fulbe society. Until recently, there was, for example, no study that analyzed the mobility of former slave groups in the Haayre region (Pelckmans, 2011). Also, studies on other areas in West Africa that do describe trajectories of former slaves often fail to differentiate between different groups of former slaves. In the aftermath of slavery, people with slave status developed multiple trajectories in so-called "post-slavery societies" (Rossi, 2009a). Like a genealogy, the different trajectories of former slave groups branched out in diverse directions. This corresponds to what Geschiere et al. (2008: 4) have called the "genealogical principle" of modernity. For example, already before abolition, there was a marked difference in the liberty of movement of slaves doing domestic work while living in with their masters, versus those slaves that cultivated land and lived slave hamlets, physically separated from their masters. The royal elites maintained their power over their "domestic" slaves well into the twentieth century, effectively immobilizing them, even if the French colonial government had legally freed them. But since the cultivating slaves had always had higher degrees of independence, abolition gave them more freedom to decide to leave or stay. There is thus also a multiplicity of experiences of mobility

4 The word Dicko literally means "vultures" and refers to the "carrion instinct" of this former warrior group.

5 On the relationship between freedom and liberty: "Liberty is the ability to move freely where one is, that is, choosing one's activities and one's associations; or moving to places where it is possible to act freely", Rossi (2009b).

6 Deutsch (2006) explains the mobility of East African slaves as a form of resistance to their exploitation. 
among people with slave status in various West African societies. As these migrants remember slavery, they take their memories of slavery with them upon moving ("moving memories").

\section{Tracking Mobility and Memory}

Not all migration trajectories allow people with slave status to disconnect from slave status, precisely because for many the ideology of slavery is intrinsically embodied and internalised. For example, Mariama, a migrant tradeswoman of hereditary slave status living in Bamako interviewed by Soares (2000), argued that money rather than ancestry currently determines one's status and therefore she considered herself a free woman. However, when her husband died, she observed the mourning rules typical for slaves, thereby embodying her slave status even though nobody asked her to do so. This is not surprising when considering that a characteristic feature of migrants is their attachment to the norms of their homelands (Bretell, 2003). Various types of intense contacts and social bonds, such as marriage arrangements, remittances and religious affiliation, keep many migrants well linked to their places of origin (Lambek, 1996; Sy, 2000; Patel and Rutten, 2003; Whitehouse, 2011). Some migrant communities are even more conservative than their compatriots back home (Nicollet quoted by Daum, 1998: 112; Sy, 2000). So not only change, but also conservatism can be a characteristic feature of migrant communities.

A common predicament of many migrants is their limited financial resources. Resources define access to jobs and hosts and often reinscribes them in networks of dependency in the place of destination. These networks can consist of strangers, or of co-villagers who installed themselves earlier in the place of destination. These so-called firstcomers of the home community are often middlemen for newcoming migrants. The data from both Bamako and Paris described below, have in common that they focus on cases in which freeborn elites successfully managed to transfer their high social status to a position of high class in cities. This is the case for the network of the Dicko family in Mali, who has a successful history in politics and education which made them upper-class residents of the city of Bamako (Pelckmans, 2007 and 2012). This is also the case for several Soninke village networks in Parisian foyers. Access to these foyers and hosts is often monopolised by older generations of migrants. Most of these first-generation Soninke migrants were elites with freeborn status who had engaged in maritime work during colonial times (Manchuelle, 1997). So, although migration holds the promise for people with slave status to escape the elite's monopoly on land and politics in the home village, many of these migrants re-engage with elites of freeborn status from their home village who are installed in the city of destination because they mediate their access to jobs and hosts. Their vulnerability results in relapsing into historical forms of dependence on former masters and freeborn status groups in the place of destination. 


\section{Travelling Hierarchies among Central Malian Fulbe Migrants in Urban Bamako, Mali}

This section demonstrates how hierarchies travel from central Mali to urban contexts with migrants of slave status. While the focus of other studies was to demonstrate how urban contexts can contribute to the emancipation from slave status, my explicit focus here is on those movements that keep the memory of slavery alive in new (urban) places. The majority of migrants from Central Mali go to Bamako during the dry season as seasonal laborers, starting aged twelve and onwards. Although there are many migrants in Bamako who come from this area, the spatial "density" of their settlement patterns once in Bamako is rather low.

This map 2 visualises how people with slave status live in different neighbourhoods than those with noble status. What is invisible on the map is that the neighbourhoods occupied by people with slave status are those neighbourhoods with poor or even no sanitation and transport facilities. The neighbourhoods, where noble families are living, are rather well-off and have good infrastructures. Since they live in different neighbourhoods, their social interactions are less frequent compared to the village. However, since the majority of the migrants with slave status sojourn only temporarily in Bamako, they have an interest in interaction with co-villagers in Bamako. For the majority of seasonal migrants of slave status their migration did not generate a break with memories of the slave past, but rather continuity. They continue their loyalty vis-à-vis their former masters. However, there are different temporalities that define this continuity; for some their movement is almost permanently in service of their masters (moving with slave status), for yet others, their movement is temporal and only takes place at specific (ritual) moments (moving back into). Below, these processes of "moving with" and "moving back into" slave status are explored and illustrated with case studies about ritual assistance and hosting.

\section{"Moving with" Slave Status towards and within Bamako}

Hosting is a central institution that has allowed people to migrate. Different ethnic groups in the West African Sahel share the same word for host, the so-called njaatigi. ${ }^{7}$ The relationship with a host or njaatigi is often established between married male heads of families and lasts over several generations through inheritance from father to son (de Bruijn and van Dijk, 1995: 161; de Bruijn, 1998: 24). Hosts contribute to feelings of belonging (de Bruijn, 2007: 125). The host is often someone from another ethnic or from another social status group, because shame relations exist between same-status group members. Hosting mechanisms were very elaborate in the Haayre region of the Fulbe network. Whenever possible, historical host-visitor relationships between specific families were used to avoid downward social mobility. This meant that one was never hosted by direct family or people of the same social status group,

7The word as it is used in Fulfulde is borrowed from the Bambara language (de Bruijn and van Dijk, 1997: 255) and its linguistic hybridity indicates in itself the interethnic aspect of most host-guest relations. Fulbe pastoralists in the Haayre region of Mali, for example, tend to have hosts among Dogon, Riimaaybe, Songhay and Hummbeebe in the plains of Seeno down south. 


\section{Map 2: Overview of settlement patterns of migrants from a Central Malian village with different status (freeborn versus slave) in Bamako}

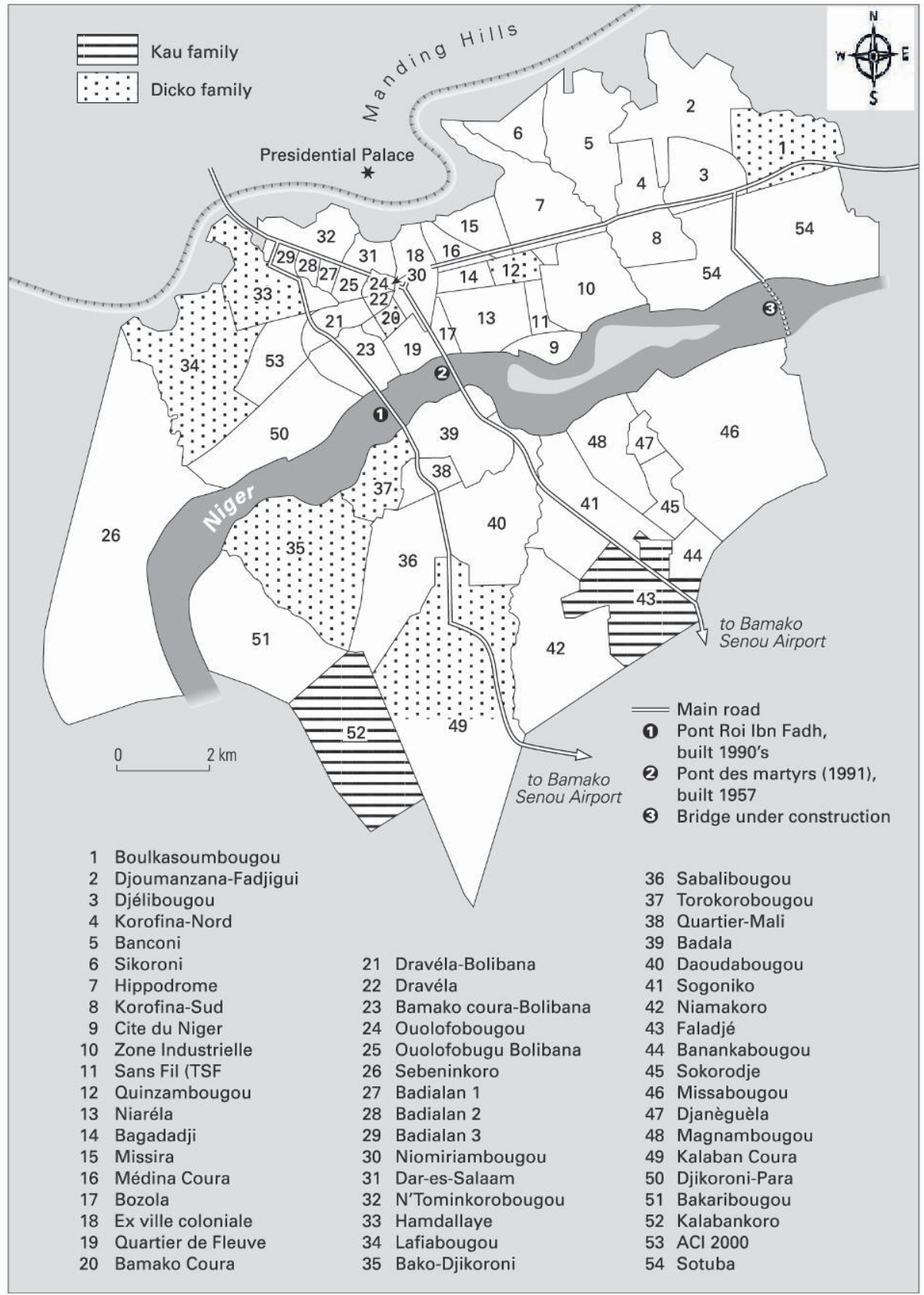

Source: Nel de Vink mapdesign. 
but preferably by people from another status groups, vis-à-vis whom rules of shame and honour had less need to be considered (de Bruijn, 2007).

In order to move, many seasonal migrants from Central Mali who have limited financial resources tend to depend on others for access to jobs and hosts in Bamako. Access to the city (and to other faraway destinations) depends on access to hosts. Most households in Bamako host relatives and neighbours from their home region, often youngsters who are studying or working (Brandt, 2001: 42). However, since migration from central Mali to Bamako remains rather recent, most migrants have no pre-existing njaatigi relations. They have to rely on hosts among family members (brothers and sisters) of the same social status group. About $80 \%$ of all migrants in the sample of the network of migrants from central Mali in Bamako were hosted by same status family members and/ or co-villagers. So in the specific case of rather recent migration from central Mali to Bamako, downward social mobility could not be prevented due to the lack of existing njaatigi relations. Those people of slave status who settled more permanently in Bamako often remained rather poor because they were expected to host as many seasonal labourers as possible. Households with people of slave status in Bamako hosted on average between six and fifteen youngsters in very basic conditions. Those of freeborn status who could afford higher living standards hosted on average between three to seven freeborn students and often also accepted one or two male seasonal migrants with slave status. However, they regularly reminded these male migrants of their slave status by asking them to do tasks corresponding to their social status such as carrying heavy bags, giving massages, taking care of the animals.

People who "move with" their slave status make their movement dependent on their social status. Often this means that people with slave status in rural areas are literally "mobilised" by freeborn elites in order to join them for work in the city. In this case there is a continuity in dependence on freeborn status groups in the city context. Mostly women migrate on demand of their masters and thus end up moving with their slave status. A concrete example is the way in which domestic workers are recruited. As I described elsewhere (Pelckmans, 2013), former Fulbe masters in the city of Bamako largely recruit their domestic workers among former slave groups in their home village or area. The domestic workers of slave status "move with" their slave status. These domestic workers of slave status embody memories of slavery both in the form of migrating as well as in the work they do. The transfer of maids of slave status to assist women of freeborn elite status in urban areas recalls the way in which slave women in the past were expected to move from the slave hamlets to the compounds of their masters to live in and do domestic work (Rodet, 2012; Pelckmans, 2013).

Opportunities to migrate and being hosted by co-villagers are also genderspecific. Women are less encouraged (or even discouraged) to move than men. Female migrants from the Haayre region depend much more than men on existing social networks to obtain work in the city, because gender defines access to different niches in the job market. Therefore, women with slave status are more likely than men to "move with" their slave status. Dependent forms of mobility whereby men "move with" their slave status are less frequent because they can engage in jobs for new patrons. In the sample of about fifty informants from the Central Mali network in Bamako, I have only encountered two cases 
of men versus fifteen of women who had literally migrated as dependants of freeborn families. The first one is a man with slave status who had been recruited in rural central Mali by his former master's family living in Bamako, to take care of the cows in a small hamlet just outside the city. The second example is that of former slave Kodo, whose ex-master Oumar had become an important politician in Bamako. Kodo was asked to move to Bamako to assist him. For two decades Kodo has lived with his wife in Oumar's compound in Bamako. Kodo currently works in the construction sector, and his wife continues to do the domestic work for Oumar. Their future (im-)mobility will most likely remain dependent on that of Oumar.

\section{"Moving back into" Slave Status: Temporary Re-embodiment of Slave Status on Ritual Occasions in Bamako}

The migrants that I will discuss below "move back into" their slave status and do so on a temporary basis. The stigma of slave status is likely to re-emerge temporarily when people move to meet with co-villagers of freeborn status in an urban context. People with slave status are the ones expected to move to their former masters' compounds to assist important ritual occasions, but not vice versa. These urban movements generate the moments "par excellence" in which the memory of slavery is re-enacted, indeed re-embodied by migrants with slave status in Bamako. The roles of people with ascribed slave status during these ritual festivities continue to be the ones that slaves used to fulfil in the past. Here too, there are marked differences between genders.

\section{Case of a Baptism among Fulbe Migrants in Bamako}

To illustrate the differences between men and women of slave status who "move back into" existing hierarchies, the birth of a newborn baby in a Fulbe elite family of freeborn status that had settled in Bamako will be analysed. ${ }^{8}$ Baby Ina is the firstborn daughter of Assi Cisse and Nassuru Dicko. Her parents are of wealthy families in central Mali that used to own domestic slaves in the past. Traditionally, mothers of freeborn status are assisted by an experienced woman with slave status during at least forty days after the birth. This is prescribed by Islamic legal provisions. ${ }^{9}$ Mother Assi was assisted by two women of slave status. One of them was her domestic worker Maya, who was asked to "move with" her slave status in order to assist Assi in Bamako. ${ }^{10}$ The second assistant was Aminata, an older woman in her fifties. Both women descend from former slaves of Assi's parents and thus come from the same home village. Aminata has been living and working as a tradeswoman at the big market in Bamako for two decades. Aminata was asked for assistance on the basis of her experience as a mother with breastfeeding. Even while living in Bamako, far from the village context, Aminata was thus asked to "move back into" her slave status. Aminata $8 \mathrm{I}$ attended five baptisms in the same social network in Bamako and I chose to describe
this one as it appeared to be the most representative.

9 According to customary interpretations of Islamic Maliki legislation, every freeborn woman has the right to be assisted by female slave descendants at several key transitions in their lives (such as giving birth, marriage, widowhood) for forty days. Women of slave status have no right to such assistance.

10 When Assi got married, domestic worker Maya was a wedding present sent by Assi's maternal family (see also Pelckmans, 2013). 
did this but was very frustrated because in order to assist mother Assi, she had to stop her trading activities with which she would have earned more money. When I asked her why she did assist Assi if it was not economically lucrative, she asked me rhetorically what else she could have done. Even though this assistance was economically unrewarding, she considered it socially impossible to refuse the demand and ignored the age-old ties of reciprocation with her co-villagers. Aminata embodied the memory of slavery and this memory was stronger than economic rationale.

Forty days after the birth, baby Ina's baptism ceremony took place on a Saturday in May 2005 in Bamako. The guests had come from different neighbourhoods in Bamako and some even travelled as far as 900 kilometres from their home village to Bamako. Baby Ina's paternal and maternal grandmothers paid the transport of their former slaves residing in the village so that they would assist and attend the event in Bamako. Considering that a one-way ticket Douentza-Bamako in 2005 cost about FCFA 10,000, these tickets represented quite a heavy investment for these families of freeborn elite status. For many of the migrants, these kinds of ritual celebrations are an occasion to eat well and catch up with fellow villagers. They assist the families of freeborn status with different types of labour, which can be compensated for in the form of food and sometimes money. For example, Hassan, a migrant of slave status from central Mali works in the construction sector in Bamako. He earns a salary and lives independent of support from the family who used to own his forefathers who also resides in Bamako. However, on ritual occasions like Ina's baptism, he feels obliged to assist and "move back into" this hierarchical relation with his former patrons. It was Hassan who dealt with the butchering of the meat after a bull was slaughtered to honour the firstborn baby.

Although the many visitors of various status backgrounds mingle, a keen observer could notice subtle differences among the social status categories by paying attention to the use of place and space. Among age mates who were sitting together drinking their tea, those of slave status would for example give up their chair when a person of freeborn elite status arrived. These differences are even more marked between women with slave and freeborn elite status in terms of activities, roles, ways of dressing and the occupation of space during such events (Pelckmans, 2011: 233-242). Women of slave status for example do not give presents to the young mother like other visitors do. They are excluded from participating in the long-lasting ties of gifts that are established between women of freeborn elite status. However, they do engage in other kinds of gift giving: they offer their labour in the form of cooking, collecting presents and distributing the food, for which at the end of the day, they can expect a material reward in return. ${ }^{11}$

The description of the baptism of Ina demonstrates how rituals are occasions for migrants in urban contexts to "move back into" existing hierarchical relations. In this urban ritual context, the division of labour and hierarchical relations remains similar to that of the village context: the butchering and cooking is done by slave descendants. Some of these slave descendants were asked to come

11 See Pelckmans (2011: chapter 7) for more details on the exact amounts redistributed for each social status group. 
over to Bamako and "moved with" their slave status, others were migrants living in Bamako who were asked to "move back into" their slave status. This organization of ritual labour, tasks and roles demonstrates how the memory of slave status is perpetuated in the urban context. The memory of slavery is also reflected in the unidirectionality of participation in ritual events: migrants of slave status visit families of freeborn elite status on ritual occasions, but not vice versa. They provide families of freeborn elite status with their labour on the ritual occasions, but not vice versa. Former masters do send money or presents to support their former slave families' ritual occasions, but do not participate in person. It remains unthinkable for them to undertake physical labour for people of slave status, especially for the ex-domestic slaves of their patrilineage. This unidirectional role division clearly echoes the labour divisions at the time of historical slavery.

\section{The Resilience of Social Status among Soninke and Fulbe Migrants in Urban Paris, France}

The case material described above so far only refers to a very specific ethnic group (Fulbe) and the destination of the migrants is their own country's capital city (Bamako). Comparing this material with material from other scholars working on African migrants in Paris, France, allows us to extend the argument to several other contexts and West African migrant groups. Indeed, I argue that both in West African as well as European cities, similar ways of "moving with" and "moving back into" slave status exist for migrants with slave status. Various researchers who describe Soninke and Fulbe migrants living in foyers in Paris, France, did not focus on legacies of slavery as such. However, all of them made reference to social struggles over the reproduction of hierarchical differences in the diaspora (Daum, 1998; Quiminal, 1991, 1996, 2002 and 2006; Timera, 1996 and 2001; Sy, 2000; Botte, 2011). Below I discuss some of these case studies and demonstrate how also in the European context, some of these specific migrants sometimes "move with" or "back into" their slave status.

\section{Dependent Mobility and Hosting}

Also in Paris hosting contributed to the maintenance of hierarchies based on slavery. Fiévet (1999) made a historical overview of African immigrant workers that have been installed in so-called "foyers" in and around Paris. Foyers still exist and are buildings which used to and continue to host migrant workers from both North and Sub-Saharan Africa. Foyers are often constructed by several companies (such as Sonacotra) which were responsible for the housing of labour migrants in the 1970's (Fiévet, 1999). Botte describes these foyers as the model of "communautarian integration" (2011: 120), often regrouping Soninke co-villagers and modeled on the "home village". Indeed, the immigrants themselves use the expression of "village-bis" to describe how hierarchical village structures are transposed to France (Daum, 1998: 113).

Botte (2011: 121) demonstrates how the control over (places in) these foyers was appropriated by traditional freeborn elites who as such managed to recreate a category of people who moved with their slave status, as dependents in the diaspora. Quiminal (1991: 56) even underlined how the way in which the travel 
among these migrants is organized, reproduced the dependence from which minors (youngsters and people with slave status) hoped to escape by migrating. So here we can draw a clear parallel between Fulbe migrants in Bamako and Soninke migrants in France who have been 'moving with' slave status through "dependent mobility".

As pointed out for Bamako, the availability of hosts defines settlement patterns of migrants in specific cities. Due to the colonial labour migration of Soninke migrants to France at the beginning of the twentieth century (Manchuelle, 1997), some of these migrants overstayed and became hosts for the new generation of postcolonial labour migrants in the 1960's. This also explains why a Fulbe migrant from eastern Mali without any historical tradition of migration to France, will have a hard time to find co-villagers in France. In contrast, a Soninke migrant from the Kayes region of western Mali who arrives in Paris will have a hard time avoiding interactions with co-villagers because they are so numerous. The foyers have a re-grouping function in which the moral economy of the village is reproduced.

\section{Moving Temporarily back into Slave Status in Paris: Associational Boards, Kitchen Revolts and Endogamous Marriages}

In his (quantitative) study on the boards of Malian Soninke and Fulbe associations in France, Daum (1998: 19) describes how hierarchical status categories are the basis for representation and recruitment of members. The hierarchies of the slave past resonate in the composition of the associational boards (see also Botte, 2011: 122). In Daum's sample (1998: 28) the key positions in the boards of these associations are occupied by people with freeborn status $(80 \%)$, versus only $17 \%$ of people with slave status. The tasks of people with slave status in the associations are often to clean the places where meetings have been held, or to inform everyone about an upcoming gathering. These tasks correspond to roles slaves historically had in the village context. Although Daum (1998: 19) underlines that there is significant social struggle surrounding this hierarchical repartition of tasks, he concludes that social hierarchies are resilient in the diaspora. Although different types of authority get intermixed in the urban context of Paris which do result in significant changes (Fiévet, 1999: 89), the board members of associations are from time to time obliged to "move back into" their slave status.

This moving back into slave status also happened and continues to happen in the kitchens of several West African migrant workers in Paris. In these kitchens, people with slave status were supposed to do the cooking for their freeborn co-habitants in the foyers. Botte (2011) describes the 1970's and 1980's revolts of people with slave status who refused to be the sole category that did the cooking for the other inhabitants of the "foyer" (Botte, 2011: 126-129). As Fiévet (1999: 177) indicates: "In the 1960's and 1970's, it was often a 'captive' who cooked these meals. Later on a rotation system was put in place." Both Botte (2011) and Fiévet (1999) present these revolts as belonging to the past. However, several of my Soninke and Ful6e informants in Paris came up with recent examples of similar struggles that are still ongoing today. After protest by some cooks with slave status who were expected to do the cooking in 2010, the kitchens of the following foyers decided to separate the money for food preparation: the foyer 
of St. Antoine and the foyer of Belleville which had close links with the foyer of Porte Dorée (metro Diderot). ${ }^{12}$

Botte (2011: 129-130) concludes that despite changes, certain aspects of the ideology of slavery remained. Strict maintenance of endogamous rules remained for example important among migrants in the diaspora. Just how violent the social struggles over love relations still are for both first and second generation West African Soninke immigrants in France is demonstrated by Yaya Sy (2000). He also indicates how families of those migrant parents who accept exogamous marriages of their children, are punished by social exclusion from the mosque and the market place of the village. Another case is ritual occasions. In 2011 an elder migrant in a Parisian foyer argued during the preparations for a burial, that since the deceased person was of noble status, more should be paid as a contribution for his burial. ${ }^{13}$ When some of the participants with lower status asked why, he pointed to "tradition" to explain the necessity to go about in this way. Informant Kone described how a person of freeborn status became very angry with an ambulant clothes vendor who refused to give him trousers on credit. ${ }^{14}$ In his anger, he insulted the vendor saying he was "an impure slave". The vendor felt insulted and they got into a physical fight. Bystanders intervened and tried to cool both men down. These examples indicate how ritual events, the choice for marriage partners and simple daily encounters of migrants from the same village or region in the urban context of Paris, potentially reproduce the ideology of slavery. The Parisian examples clearly resonate with the way in which Fulbe migrants in Bamako are expected to temporarily "move back into" their ascribed social status.

\section{Conclusion: Options to "Move back into" or to "Move with" Slave Status?}

Migrants' movements reflect embodied memories of the slave past. Although the official stance vis-à-vis slavery in West African public spheres is that slavery is something of the past, categorical slavery continues to be present in various ethnic groups of West Africa. More specifically I have demonstrated how it reverberates in the lives and movements of Fulbe and Soninke who moved to the urban contexts of either Bamako or Paris.

This contribution has explored the extent to which the movements of migrants with slave status are linked to their slave past. Social status "ranks" different kinds of movements. In both Bamako and Paris, the freeborn elites recreated their high status in the diaspora. The freeborn in the network of Fulbe migrants from Central Mali, were pioneers in colonial education and obtained jobs in the state apparatus. This was not the case for those with slave status, who after migrating to Bamako became part of the lower working class. The Paris material focused on so-called "foyers", which are buildings that have regrouped African workers in France ever since the 1970s. Specific to the Fulbe and Soninke

12 Informant Kone, Interview May 2012, Paris.

13 Informant Timera, Interview September 2012, Paris.

14 Informant Kone, Interview May 2012, Paris. 
migrants of Mali, Mauritania and Senegal in Paris, is that some of these foyers have been monopolized by villages of the home area. This facilitated social control and the travelling of hierarchies from the home country into the diaspora community. Some foyers became the "village-bis" in Europe, a community that is strongly attached to copying a moral economy of the "traditional" home context. In both cases, the elites with freeborn status in the diaspora have lost important forms of monopolies, which secured their power in the village context (land, political positions), but at the same time they have acquired new ones in the urban context (access to high status jobs and becoming important hosts). Memories of slavery are not constantly fore grounded in the daily lives of all migrants, but migrants often do relapse temporally into hierarchical forms of relating with families of freeborn status. This demonstrates how categorical slavery is a very real aspect of these (migrant) communities, also in urban contexts.

A typology of five possible trajectories of movements by people with ascribed slave status has been developed. These qualities of movement underline the continued importance of memories of slavery among specific groups of West African migrants in urban contexts. Two forms of these movements reflect continuities in categorical slavery within a moral community of migrants in Paris and Bamako: "moving with" and "moving back into" social status. Migrants - often women - who "moved with" their slave status did so because they had no other viable options to pay for their movement or housing unless they accepted to rely on existing hierarchical networks. In Paris also the hosting networks in foyers has often recreated existing social relations between co-villagers. The analysis has demonstrated how for these specific networks of Fulbe and Soninke migrants, migration did not enhance emancipation, but consolidated existing memories of slavery and slave status.

These loyal forms of moving either with or back into slave status represent different temporalities and are gendered. In the past, slave women used to have roles that were much more time-consuming than men at key moments in their masters' lives. Also today, assistance continues to be more demanding for migrant women with slave status than for men. So the temporality of the re-embodiment of slave status is much longer for women than for men. Domestic workers "move with" their social status and are almost permanently reminded of their slave status, while men are only temporarily reminded of their status when moving back into existing hierarchies on ritual occasions. In both Bamako and Paris, ritual occasions and marriage alliances allow for fulfilling the desire for moral integrity, belonging and sharing with the home community. These are the occasions par excellence to reproduce existing patterns of interaction between co-villagers of different social status in the city.

This article has focussed on those movements whereby people remain or return to the "loyalty" option vis-à-vis the ideology of slavery. The way in which people of slave status move with or back into that status in urban contexts, is a form of collective remembering of internal African slavery. This memory work tends to be non-discursive and is embodied in the movements of people. 


\section{References}

Argenti Nicolas and Röschenthaler Ute (2006) Introduction: Between Cameroon and Cuba: Youth, Slave Trades and Translocal Memoryscapes, Social Anthropology, 14 (1), pp. 33-47.

Bellagamba Alice (2009) After abolition: Metaphors of slavery in the political history of the Gambia, in Benedetta Rossi Ed., Reconfiguring Slavery: West African Trajectories, Liverpool, Liverpool University Press, pp. 116-139.

Botte Roger (2011) Esclaves et prolétaires : les migrants soninkés en France, La Pensée, 386, pp. 119-130.

Botte Roger (2003) Le droit contre I'esclavage au Niger, Politique Africaine, 90, pp. 127-143.

Botte Roger (2000) De l'esclavage et du daltonisme dans les sciences sociales: avant-propos, Journal des Africanistes, 70 (1-2), pp. 7-42.

Botte Roger (1999) Préface : I. Un peul peut en cacher un autre : délivrances, in Roger Botte, Jean Boutrais et Jean Schmitz Éds., Figures Peules, Paris, Karthala, pp. $12-18$.

Bouche Denise (1968) Les villages de liberté en Afrique noire française, 18871910, Paris, Mouton, 278 p.

Bouman Annemarie (2002) Benefits of belonging. Dynamics of Iklan identity, Burkina Faso, Phd thesis, Leiden University, [online] last checked on 26/02/2013. URL: http://www.unitedacademics.org/library/publication/475772/

Boyer Florence (2005) L'esclavage chez les Touaregs de Bankilare au miroir des migrations circulaires, Cahiers d'études africaines, 45 (179-180), pp. 771-804.

Brand Saskia (2001) Mediating Means and Fate: A Socio-Political Analysis of Fertility and Demographic Change in Bamak, Leiden, Brill, 360 p.

Breedveld Anneke et De Bruijn Mirjam (1996) L'image des Fulbe : Analyse critique de la construction du concept de Pulaaku, Cahiers d'études africaines, 36 (144), pp. 791-821.

Bretell Caroline (2003) Anthropology and Migration: Essays on Transnationalism, Ethnicity, and Identity, Walnut Creek, Alta Mira Press, 272 p.

Clark Andrew F. (1999) The ties that bind: servility and dependency among the Fulbe of Bundu (Senegambia), c. 1930s to 1980s, in Martin Klein and Suzanne Miers Eds., Slavery and Colonial Rule in Africa, London, Frank Cass, pp. 73-90.

Daum Christophe (1998) Les associations de Maliens en France, Paris, Karthala, $253 \mathrm{p}$.

De Bruijn Mirjam and Pelckmans Lotte (2005) Facing dilemmas: Former Fulbe slaves in modern Mali, Canadian Journal of Cultural Anthropology, 39 (1), pp. 69-96.

De Bruijn Mirjam and Van Dijk Han (2000) Fulbe Mobility: Migration and Travel into Mande, Mande Studies, 1, pp. 41-62.

De Bruijn Mirjam et Van Dijk Han (1997) Peuls et Mandingues : Dialectique des constructions identitaires, Paris, Karthala, 286 p. 
De Bruijn Mirjam and Van Dijk Han (1995) Arid Ways: Cultural Understandings of Insecurity in Fulbe Society Central Mali, Amsterdam, Thela Publishers.

De Bruijn Mirjam, Van Dijk Rijk and Foeken Dick (2001) Mobile Africa: An introduction, in Mirjam de Bruijn, Rijk Van Dijk and Han Van Dijk Eds., Mobile Africa: Changing Patterns of Movement in Africa and Beyond, Leiden, Brill, pp. 1-7.

De Jong Ferdinand (2010) Silences that speak to the slave trade, Cahiers d'études africaines, 50 (197), pp. 319-331.

Deutsche Jan Georg (2006) Emancipation without Abolition in German East Africa, c.1884-1914, Oxford, Ohio University Press, 320 p.

Diarra H. (1998) De Bamako à Paris et vice versa, Demain le monde, 24/25, pp. 38-39.

Diawara Mamadou (1990) La graine de la parole : dimension sociale et politique des traditions orales du royaume de Jaara (Mali), du XVe au milieu du XIXe, Stuttgart, Franz Steiner Verlag, 154 p.

Diawara Mamadou (1989) Femmes, servitude et histoire : les traditions orales historiques des femmes de condition servile dans le royaume de Jaara (Mali) du XVe au milieu du XIXe siècle, History in Africa, 16, pp. 71-96.

Dupire Marguerite (1970) Organisation sociale des Peuls, Paris, Plon, 624 p.

Evers Sandra (2002) Constructing History, Culture and Inequality: The Betsileo in the Extreme Southern Highlands of Madagascar, Leiden, Brill Publishers, 225 p.

Fanchette Sylvie (1999) Migrations, intégrations spatiales et formation d'une société peule dans le Fouladou (haute Casamance, Sénégal), in Roger Botte, Jean Boutrais et Jean Schmitz Éds., Figures Peules, Paris, Karthala, pp. 165-192.

Fay Claude (2002) Décentralisation et réhiérarchisation des pouvoirs dans le cercle de Tenenkou, in Yaouaga Félix Koné and Claude Fay Éds., Pouvoirs locaux, pouvoir d'état, démocratie et décentralisation au Mali, Den Haag, ISH, pp. 131-182.

Ferguson James (1999) Expectations of Modernity: Myths and Meanings of Urban Life on the Zambian Copperbelt, Berkeley, University of California Press, 343 p.

Fiévet Michel (1999) Le livre blanc des travailleurs immigrés des foyers : du non-droit au droit, L'Harmattan/Ciemi, Paris, 272 p.

Finley Moses I. (1981) Esclavage antique et idéologie moderne, Paris, Minuit, $216 \mathrm{p}$.

Fontaine Sandra (2003) Voyage sans retour?, Jeune Afrique, 2231, pp. 68-70.

Gaibazzi Paolo (2012) The rank effect: postemancipation immobility in a Soninke village, The Journal of African History, 53 (2), pp. 215- 234.

Geschiere Peter L., Meyer Birgit and Pels Peter (Eds) (2008) Readings in Modernity in Africa, Edinburgh, Edinburgh University Press, 256 p.

Giuffrida Alessandra (2005) Métamorphoses des relations de dépendance chez les Kel Antessar du cercle de Goundam, Cahiers d'études africaines, 45 (179$180)$, pp. $805-830$.

Hahn Hans-Peter and Klute Georg (2007) Introduction, in Hans-Peter Hahn and Georg Klute Eds, Cultures of Migration: African Perspectives, New Brunswick, Transaction Publishers, pp. 9-27. 
Hahonou Eric (2009) Slavery and politics: Stigma, decentralisation and political representation in Niger and Benin, in Benedetta Rossi Ed., Reconfiguring Slavery: West African Trajectories, Liverpool, Liverpool University Press, pp. 152-181.

Hahonou Eric and Pelckmans Lotte (2012) "History must be rewritten!": National Histories of Domestic West African Slavery Revisited, in Douglas Hamilton Ed., Slavery, memory and identity: national representations and global legacies, London, Pickering and Chatto, pp. 92-104.

Hahonou Eric and Pelckmans Lotte (2011) Citizenship struggles: social movements and slavery in West Africa, Vienna Journal of African Studies, 20, pp. 141-162.

Hall Bruce S. (2005) The question of "race" in the pre-colonial Southern Sahara, Journal of North African Studies, 10 (3-4), pp. 339-367.

Hardung Christine (2002) The everyday life of slaves in Northern Dahomey: The process of remembering, Journal of African Cultural Studies, 15 (1), pp. 35-44.

Hardung Christine (1998) Exclusion sociale et distance voulue : Des rapports entre les Gannunkeebe et les Fulbe, in Élisabeth Boesen, Christine Hardung et Richard Kuba Éds, Regards sur le Borgou : Pouvoir et altérité dans une région ouest-africaine, Paris, L'Harmattan, pp. 203-219.

Hesseling Gerti and Van Dijk Han (2005) Administrative decentralization and political conflict in Mali, in Patrick Chabal, Ulf Engel and Anna-Maria Gentili Eds., Is Violence Inevitable in Africa? Theories of Conflict and Approaches to Conflict Prevention, Leiden, Brill, pp. 171-192.

Hirschman Albert O. (1970) Exit, Voice, and Loyalty: Responses to Decline in Firms, Organizations, and States, Cambridge, Harvard University Press, 162 p.

Keita Naffet (Éd.) (2012) L'esclavage au Mali, L'Harmattan, Paris, 157 p.

Klein Martin (1998) Slavery and Colonial Rule in French West Africa, Cambridge, Cambridge University Press, 354 p.

Klein Martin and Miers Suzanne (1999) Introduction, in Martin Klein and Suzanne Miers Eds., Slavery and Colonial Rule in Africa, London, Frank Cass, pp. 1-15.

Klein Martin and Richard Roberts (1980) The Banamba slave exodus of 1905 and the decline of slavery in the western Sudan, Journal of African History, 21 (3), pp. 357-394.

Kopytoff Igor (1987) The African Frontier: The Reproduction of Traditional African Societies, Bloomington, Indiana University Press, 296 p.

Kopytoff Igor and Miers Suzanne (1977) African "Slavery" as an Institution of Marginality, in Suzanne Miers and Igor Kopytoff Eds., Slavery in Africa: Historical and Anthropological Perspectives, Madison, University of Wisconsin Press, pp. 3-83.

Lambek Michael (1996) The Past Imperfect: Remembering as Moral Practice, in Paul Antze and Michael Lambek Eds., Tense Past: Cultural Essays in Trauma and Memory, London, Routledge, pp. 235-254.

Lefebvre Camille (2013fc) Un esclave a vu le monde. Se déplacer en tant qu'esclave au Soudan central (XIXe siècle), Locus, 35 (18).

Leservoisier Olivier (2009) Contemporary Trajectories of Slavery in Haalpulaar Society (Mauritania), in Benedetta Rossi Ed., Reconfiguring Slavery: West African Trajectories, Liverpool, Liverpool University Press, pp. 140-151. 
Leservoisier Olivier (2005) " Nous voulons notre part ! " Les ambivalences du mouvement d'émancipation des Saafaalbe Hormankoobe de Djéol (Mauritanie), Cahiers d'études africaines, 45 (179-180), pp. 987-1014.

Lovejoy Paul E. (2009) The slave trade as enforced migration in the central Sudan of West Africa, in Richard Bessel and Claudia Haake Eds., Removing Peoples: Forced Removal in the Modern World, London, German Historical Institute, pp. 145-164.

Lovejoy Paul E. (Ed.) (1981). The Ideology of Slavery in Africa, Beverly Hills and London, Sage Publications, 307 p.

Manchuelle François (1997) Willing Migrants: Soninke Labor Diasporas, 18481960, Athens, London, Ohio University Press, James Currey, 371 p.

Mauxion Aurelien (2008) Rice farming intensification and political enterprise in northern Mali, Politique africaine, 110, pp. 153-169.

Meillassoux Claude (1986) Anthropologie de l'esclavage : le ventre de fer et d'argent, Paris, Presses universitaires de France, 375 p.

Meillassoux Claude (Éd.) (1975) L'esclavage en Afrique précoloniale. Paris, Maspero $582 \mathrm{p}$.

Miers Suzanne (2003) Slavery in the 20th Century. The Evolution of a Global Problem, Oxford, Rowman and Littlefield (NBN), 496 p.

Miers Suzanne and Willis Justin (1997) Becoming a child of the house: Incorporation, authority and resistance in Giryama society, The Journal of African History, 38 (3), pp. 479-495.

Nora Pierre (1984) Entre mémoire et histoire, in Pierre Nora Éd., Les lieux de mémoire, T. 1 La République, Paris, Gallimard, pp. XXV-ILII.

Ould Ahmed Salem Zekeria (2003) Droit du statut personnel en République Islamique de Mauritanie, La Pensée, 336, pp. 37-53.

Pelckmans Lotte (2014fc) Stained ancestry: truncated genealogies and kinship among descendants of slaves in Mali, Civilizations (paper proposed for special issue "Ancestry Revisited").

Pelckmans Lotte (2013fc) Surnames as a passport to social mobility, in Alice Bellagamba, Carolyn Brown, Sandra Greene and Martin Klein Eds., Tales of slavery: looking for alternate Tracks (provisional title), Trenton, Africa world Press.

Pelckmans Lotte (2013) Dependent mobilities of domestic workers as memoryscapes of slavery in urban Fulbe families in Mali, in Joel Quirk and Darshan Vigneswaran Eds., Slavery, migration and contemporary bondage, Trenton, Africa world Press.

Pelckmans Lotte (2012) "Having a road": social and spatial mobility of persons of slave and mixed descent in post-independence Central Mali, Journal of African History, 53 (2), pp. 235-255.

Pelckmans Lotte (2011) Travelling hierarchies: Moving in and out of slave status in a Central Malian Fulbe network, African Studies collection, 34, Leiden.

Pelckmans Lotte (2009) Phoning anthropologists: The mobile phone's (re-) shaping of anthropological research, in Mirjam de Bruijn, Francis Nyamnjoh and Inge Brinkman Eds., Mobile Phones: the New Talking Drums of Everyday Africa, Bamenda, Langaa, Leiden, ACS, pp. 23-49. 
Pelckmans Lotte (2007) Negotiating the memory of Fulbe hierarchy among mobile elite women, in Mirjam de Bruijn, Rijk van Dijk and Jan-Bart Gewald Eds, Strength beyond Structure: Social and Historical Trajectories of Agency in Africa, Leiden, Brill, pp. 285-311.

Pollet Éric and Winter Grace (1971) La société Soninké (Dyahunu, Mali), Bruxelles, Éditions de l'Institut de Sociologie, 556 p.

Quiminal Catherine (2006) Décentralisation, démocratie et migrations dans la région de Kayes, in Claude Fay, Yaouaga Félix Koné et Catheirne Quiminal Éds., Décentralisation et pouvoirs en Afrique : En contrepoint, modèles territoriaux français, Paris, IRD, pp. 239-262.

Quiminal Catherine (2002) Nouvelles mobilités et anciennes catégories, VilleÉcole-Intégration Enjeux, 131, pp. 9-23.

Quiminal Catherine (1996) Parcours de femmes d'Afrique subsaharienne en France : De la polygamie à la famille monoparentale, in Jeanne Bisilliat Éd., Femmes du Sud, chefs de famille, Paris, Karthala, pp. 223-232.

Quiminal Catherine (1991) Gens d'ici, gens d'ailleurs : migrations soninké et transformations villageoises, Paris, Christian Bourgois, 222 p.

Riesman Paul (1992) First Find your Child a Good Mother: the Construction of Self in two African Communities, New Brunswick, N.J., Rutgers University Press, 241 p.

Riesman Paul (1977 [1974]) Freedom in Fulani Social Life: an Introspective Ethnography, Chicago, London, The University of Chicago Press, 314 p.

Rodet Marie (2012) "Under the Guise of Guardianship and Marriage": Mobilizing Juvenile and Female Labor in the Aftermath of Slavery in Kayes, French Soudan, 1900-1939, in Benjamin N. Lawrance and Richard L. Roberts Eds., Trafficking in Slavery's Wake. Law and the Experience of Women and Children in Africa, Athens, Ohio University Press, pp. 86-100.

Rodet Marie (2010) Les migrantes ignorées du Haut-Sénégal (1900-1946), Paris, Karthala, 348 p.

Rodet Marie (2010) Mémoires de l'esclavage dans la région de Kayes, histoire d'une disparition, Cahiers d'études africaines, 50 (197), pp. 263-291.

Rossi Benedetta (2009a) Introduction: Rethinking slavery in West Africa, in Benedetta Rossi Ed., Reconfiguring Slavery: West African Trajectories, Liverpool, Liverpool University Press, pp. 1-25.

Rossi Benedetta (2009b) Slavery and migration: Social and physical mobility in Ader (Niger), in Benedetta Rossi Ed., Reconfiguring Slavery: West African Trajectories, Liverpool, Liverpool University Press, pp. 182-206.

Ruf Urs Peter (1999) Ending Slavery: Hierarchy, Dependency and Gender in Central Mauritania, New Brunswick, London, Transaction Publishers, 434 p.

Saibou Issa (2005) Paroles d'esclaves au Nord-Cameroun, Cahiers d'études africaines, 45 (179-180), pp. 853-878.

Sanankoua Bintou (1990) Un empire Peul au XIXe siècle : La Diina du Maasina, Paris, Karthala et ACCT, $180 \mathrm{p}$.

Schmitz Jean (2007) Des migrants aux notables urbains : Les communautés transnationales des gens du fleuve Sénégal (Sénégal/Mali/Mauritanie), in Élisabeth Boesen et Laurence Marfaing Éds., Les nouveaux urbains dans l'espace Sahara-Sahel : Un cosmopolitisme par le bas, Paris, Karthala, pp. 91-134. 
Schmitz Jean (2009) Islamic patronage and republican emancipation: The slaves of the Almaami in the Senegal River valley, in Benedetta Rossi Ed., Reconfiguring Slavery: West African Trajectories, Liverpool, Liverpool University Press, pp. 85-115.

Shaw Rosalind (2002) Memories of the Slave Trade, Chicago/London, The University of Chicago Press, 320 p.

Soares Benjamin F. (2000) Notes on the Anthropological Study of Islam and Muslim Societies in Africa, Culture and Religion, 1 (2), pp. 277-285.

Sy Yaya (2000) L'esclavage chez les Soninkés : du village à Paris, Journal des africanistes, 70 (1-2), pp. 43-69.

Testart Alain (1998) L'esclavage comme institution, L'Homme, 145, pp. 31-69.

Thioub Ibrahima (2005) Regard critique sur les lectures africaines de l'esclavage et de la traite atlantique, in Issiaka Mandé et Blandine Stefanson Éds., Les historiens africains et la mondialisation, Paris, Karthala, pp. 271-291.

Tidjani Alou M. (2000) Démocratie, exclusion sociale et quête de la citoyenneté : cas de I'association Timidria au Niger, Journal des Africanistes, 70 (1-2), pp. 173-196.

Timera Mahamet (2001) Les migrations des jeunes Sahéliens : affirmation de soi et émancipation, Autrepart, 18, pp. 37-49.

Timera Mahamet (1996) Les Soninké en France, Paris, Karthala, 244 p.

Trouillot Michel-Rolph (1995) Silencing the Past: Power and the Production of History, Boston, Beacon Press, 216 p.

Vereecke Catherine (1994) The slave experience in Adamawa: Past and present perspectives from Yola (Nigeria), Cahiers d'études africaines, 34 (133-135), pp. 23-53.

Whitehouse Bruce (2011) Approche comparative des familles dispersées (MaliCongo) : éducation et espaces nationaux, Autrepart, 57-58, pp. 233-246. 


\section{Lotte Pelckmans}

\section{... Moving Memories of Slavery among West African Migrants in Urban Contexts (Bamako, Paris)}

"Moving memories of slavery" are those memories of internal African slavery that move with West African migrants to urban areas. Different types of mobility towards and within urban contexts can be considered as non-discursive, embodied forms of 'memory work' of slavery. The focus is on how Fulbe (and Soninke) migrants in Bamako and Paris 'move with' or 'move back into' slave status on specific moments in space and time. Even though cities offer opportunities to silence memories about their slave past, this can be only temporal and necessarily intersects with age, class, gender, etc. The data presented demonstrate that under specific conditions, urban contexts can also reproduce - even if temporarily - stigma, labour divisions and hierarchical inequalities related to the memory of slavery.

\section{Mémoires itinérantes de l'esclavage chez les migrants ouest-africains en contexte urbain (Bamako, Paris)}

Cet article met en lien la mobilité des migrants issus de sociétés fortement stratifiées par la mémoire de l'esclavage interne en Afrique de l'Ouest. L'auteure utilise une typologie des formes de mobilité qui considère la mobilité vers et au sein de la ville comme un " travail de mémoire " non-discursif et incorporé de l'esclavage. Elle s'intéresse en particulier à la façon dont les migrants peuls (et soninké) se déplacent avec leur statut social d'esclave vers et dans les villes de Bamako et Paris. Même si les villes offrent des possibilités de faire taire les mémoires du passé esclavagiste, cela n'arrive souvent que de façon temporaire et en interaction avec l'âge, le genre, etc. Les données montrent comment le contexte urbain peut aussi reproduire - même de manière temporaire - les stigmates et les inégalités hiérarchiques basés sur la mémoire de l'esclavage.

\section{Memorias de esclavitud en movimiento entre migrantes de África occidental en contextos urbanos (Bamako, Paris)}

La memoria de la esclavitud surge en la diáspora urbana donde las posiciones sociales se reproducen entre las personas "libres" y los descendientes de esclavos. El material se enfoca en los migrantes Fulaníes (y Soninke) venidos a Bamako y Paris. Las memorias de un pasado de esclavitud continúan a ser vividas en interacciones diarias entre los grupos de libres y los grupos que llevan un estatuto de esclavos en el contexto urbano. El artículo contraría la retórica generalizada que presenta la urbanización como el proceso por excelencia de individualización y por lo tanto de emancipación de esclavos. Los contextos urbanos no siempre ofrecen a ciertos individuos con estatuto de esclavo las oportunidades necesarias para silenciar recuerdos sobre sus pasados en la esclavitud. Bajo ciertas condiciones, las posiciones sociales no son silenciadas, pero al contrario, el estatuto de esclavo puede ser reproducido y recordado de forma explícita. 